\title{
16. The Contest for Rural Representation: The celebrated contest over Indi and the fate of the independents
}

\author{
Jennifer Curtin and Brian Costar
}

Over the past decade, independent parliamentarians have become a recurring feature of Australian federal politics (and elsewhere). This has sparked speculation about the extent to which independents represent a permanent challenge to the stability of two-party-dominant systems, both in Australia and internationally. ${ }^{1}$ At the state level, independents have regularly held the balance of power and federally, in the Senate, there have been occasions when independents as well as minor parties have shared the title of power broker. Consequently, over the past 20 years there has been occasional scholarly debate over whether the vote for 'other' parties represents a fragmentation of the two-party system and a decline in the strength of party identification as a key determinant of voting behaviour. ${ }^{2}$ Yet survey data still tell us that around 80 per cent of voters continue to identify as either Labor or Liberal and such loyalty sets Australia apart from many of its contemporaries (Bean and McAllister 2012). This suggests that independents may indeed be just a passing phase for momentarily disaffected voters.

Yet the historic hung parliament election of 2010 ensured independents took centre stage in a way not seen federally since 1940. Although the percentage of party identifiers remained solid in 2010, with the combined primary vote for the Labor and the Coalition parties at 81 per cent and only 2.5 per cent of voters opting for independents (Brent 2013), support for the latter was sufficiently concentrated in key electorates to return three sitting rural independents (Bob Katter, Rob Oakeshott and Tony Windsor) and elect one other from Tasmania (Andrew Wilkie). These four regional independents, along with the Greens' Adam Bandt and Western Australian Nationals' Tony Crook, were involved in 17 days of government formation negotiations and ultimately became the focus of much opposition and media speculation over the next three years.

So does this mean independents are a passing phase or becoming a new 'tradition' in Australian federal politics? The remainder of this chapter attempts

1 For examples of this literature, see: Brancati (2008); Costar and Curtin (2004); Hijino (2013); Rodriques and Brenton (2010); Smith (2006); Weeks (2009 and 2011).

2 These issues have been discussed in more depth in: Bean and Papadakis (1995); Curtin (2004); Moon (1995); Papadakis and Bean (1995). 
to answer this question through an analysis of the work of independents in the 43rd parliament (2010-13) and the support they received in the election of 2013. The expectation was that fatigue and disaffection with the perceived instability of a minority government would drive voters to return to the more traditional choices, and the predictable result of an inflated majority for the LiberalNational Coalition. The retirement of Oakeshott and Windsor also fuelled the assumption that independents were unlikely to feature again significantly.

Nevertheless, the Coalition failed to predict one outcome - that of the rural Victorian seat of Indi where voters elected local independent Cathy McGowan over sitting Liberal member Sophie Mirabella. The final section of this chapter offers a detailed review of this result. In some ways Indi was unusual-McGowan is only the third female federal independent ${ }^{3}$ and her campaign included a combination of new and traditional strategies that together ensured coverage of a diverse and geographically sizeable rural electorate, appealing to both young and old. Moreover, her win goes against predicted expectations that independents are more likely to stand and potentially be successful when running against a government incumbent rather than a member of the opposition. Conversely, McGowan's success builds on what has become a tradition in Australian politics. Rural constituencies feel forgotten by marginal seat election campaigns run by the major parties, so supporting independents is viewed as a tactical alternative. This rebellious streak amongst otherwise conservative voters, in combination with a general ambivalence about the capacity of major parties to represent local interests, suggests that there will continue to be possibilities for other 'McGowan-like' successes in rural and regional Australia.

\section{The role played by independents and the 43rd parliament}

In one sense there was an element of instability in the composition of the 43rd parliament. Although the three incumbent rural and regional independents were a known quantity, the number of parliamentarians who sat on the cross benches fluctuated during this period. West Australian National Tony Crook began his term on the cross benches, separating himself from the federal Nationals and labelling himself an independent representing Western Australian interests. He voted on confidence and supply with the Coalition but also supported the Labor Government on a range of issues. Crook formally joined the federal Nationals in

3 Before McGowan's election, both Doris Blackburn in 1946 (Burke) and Pauline Hanson in 1996 (Oxley) had won lower house seats as independents in the federal parliament - although Hanson technically was a disendorsed Liberal candidate (and appeared on the ballot paper as such) and then formed her own One Nation party. 
parliament in May 2012, taking the Coalition's seats to 72 compared to Labor's 71. Surprisingly, he did not contest the 2013 poll and O'Connor reverted to the Liberal Party. By contrast, Peter Slipper began the 43rd parliament as the Liberal National Party MP for Fisher but became an independent in September 2011 when he was elected Speaker - a post from which he was forced to resign in September 2012. Craig Thomson also became a nominal independent after a post-scandal exit from the Labor Party in September 2012, while newly elected Tasmanian independent Andrew Wilkie rescinded his guaranteed support for the Government in January 2012.

Despite these fluctuations in cross bench membership, Labor continued to govern, with 561 government bills passed, up from just over 400 in the 42nd parliament (Hawker Britton 2013a). More specifically, over the course of the 43rd parliament there were 491 divisions and, with the support of independents, the Government won the majority in 93.5 per cent of divisions on substantive matters and in 81 per cent of all divisions. There were some amendments to bills but ultimately no government-sponsored bill was defeated on the floor of the House of Representatives (Hawker Britton 2013a).

Percentage support for government bills is a blunt means by which to measure the performance of a government. However, the Gillard Government's capacity to get its legislation passed (in terms of both daily business and more substantive policy changes) also compares well when measured against previous Australian governments since federation. Nick Evershed assigned all Commonwealth of Australia Numbered Acts $^{4}$ to a prime minister, political party and parliament based on the date of assent of the Act. He then counted the total Acts for each PM, party and parliament, determined the number of days in office for each PM, and the number of days each parliament and party governed. Using these figures Evershed calculated the rate of Acts per day, which accounted for different lengths of prime ministers' or governments' terms. His results demonstrate that the Gillard Government had the highest rate of passing legislation at 0.495, followed by Bob Hawke at 0.491 (Evershed 2013).

This overarching stability and productivity did not mean the independents acted as Labor 'lackeys'. Individual voting patterns show some variation between the independents across a range of substantive and procedural issues. More generally, Andrew Wilkie voted with the Government in 73 per cent of divisions; Tony Windsor in 75 per cent and Rob Oakeshott in 76 per cent. Although Bob Katter chose not to support Labor formally, he only voted against the Government in 36 per cent of divisions and was conspicuous by his absence (in 37 per cent of divisions). This contrasts with Tony Crook who, while avowedly independent, voted with the Coalition in 88 per cent of divisions (Hawker Britton 2013a).

$4<$ www.austlii.edu.au/au/legis/cth/num_act/>. 
However, on Labor's seven key policy areas (carbon pricing, minerals resource rent tax, education and school improvement, national disability insurance, national broadband, aged care and tobacco plain packaging) both Windsor and Oakeshott were solid supporters of the Government's position (Hawker Britton 2013b).

Finally, significant procedural changes were implemented during the 43rd parliament as a result of Oakeshott and Windsor including an annex to their agreement to support a Labor Government. The Agreement for a Better Parliament: Parliamentary Reform facilitated an increase in the Selection Committee's referral of private members' bills, the number of questions asked by private members in Question Time, a stronger role for the Speaker in managing Question Time and an increase in time given to private members' business in the House (Parliamentary Library 2013). These procedural changes continue a tradition of Australian independents working to secure good governance and stronger accountability (Costar and Curtin 2004; Smith 2006).

The reforms also enabled independents to take up issues that mattered to their constituents or that had a national focus but were not major party policy. Seventysix private members' bills were introduced in the House of Representatives, 33 of which were sponsored by the independents. These bills dealt with a range of policy issues; from migration and asylum seekers to environmental protection; from consumer protection and food labelling to restrictions on live animal exports. While only six private members' bills were passed, two of which were initiated by independents (the Auditor-General Amendment Bill and Evidence Amendment Journalists' Privilege Bill), the process of allowing additional debate and consideration has been considered an important institutional change to the workings of the Australian parliament (Parliamentary Library 2013). The valedictory speeches by Oakeshott and Windsor also indicate that the independents saw themselves as having made a substantive contribution to the process of governing and to the institution of parliament (Oakeshott 2013; Windsor 2013).

\section{Election 2013 and the independents}

Although threats of no-confidence votes and predictions of instability and policy paralysis abounded, Labor and the independents were able to sustain an amicable and productive relationship in both political and policy terms (Hawker Britton 2013a), and despite Wilkie rescinding his guaranteed support, he supported the majority of the Government's bills during this term 
(73 per cent of divisions). Moreover three Budgets were passed and no motions of no-confidence were moved against either the executive or the prime minister (Oakeshott 2013).

Despite this reality, the Coalition parties' campaign strategy in 2013 targeted sitting independents, encouraging voters to see support for independents as a waste of a vote (McKenna and Maher 2013) and linking such support to the risk of continued 'unstable' government (Maher 2013). Nevertheless, throughout the 2013 campaign, Newspoll indicated that a considerable minority of voters continued to show an interest in supporting non-major parties and independents. In the six weeks of the campaign, the primary vote for 'others' stood at 10 per cent on 2 August and hovered around this figure right up to the week of the election (by which time it had increased slightly to 12 per cent) (Newspoll 2013a). In Oakeshott's electorate of Lyne and Windsor's electorate of New England, the support for 'others' stood at 18 and 16 per cent respectively, although ultimately both these electorates were won by the Coalition (Newspoll 2013b). While the actual vote for 'others' nationally (excluding the Palmer United Party and Katter's Australia Party) was much lower than the polls predicted (at around 5.5 per cent), it was sufficiently concentrated in Tasmania and Indi to ensure the re-election of Wilkie and the election of a new independent, Cathy McGowan, in Indi.

However, the former independent Bob Katter did not fare so well in Kennedy. Perhaps because Oakeshott and Windsor were retiring, Katter became a key target of the negative campaigning by the Liberal National Party. 'Katternomics' was ridiculed (Neales 2013) and large advertisements appeared in the CourierMail urging voters in Kennedy not to vote Katter's Australia Party (KAP). While Katter ultimately held his seat, his micro party won no Senate seats and Katter's majority in Kennedy decreased by 18 points (to 52.2 per cent in two-candidatepreferred terms).

The phenomenon of micro parties became the new 'obsession' in this campaign (see Tom King's Chapter 17), drawing attention towards the Senate and away from any consideration of independents in the House of Representatives election. This reaction is unsurprising. Despite Labor's change in leadership, it was almost a foregone conclusion that the Coalition would win a healthy majority in the House and, if the primary vote was sufficiently high, there was hope this would translate into large wins in the Senate. However, preference deals between micro parties for Senate seats and between independents in the lower house (Wilkie) and the Senate (Xenophon) posed a threat to both major parties. This distraction was to prove most costly to the Coalition. Although they won 90 seats in the House, including a number of previously ALP-held rural and regional seats, 30 per cent of these remain marginal-the same percentage as 
in 2010 (AEC 2013; Curtin and Woodward 2012). ${ }^{5}$ Rural discontent with the Coalition parties was evident in Mallee where the Nationals faced a campaign to 'Make Mallee Marginal' (Ferguson 2013). More significantly, the Liberals inadvertently lost the previously safe seat of Indi, suggesting the idiosyncrasies of the preferential majoritarian electoral system and continuing anti-majorparty sentiment in rural Australia can be mobilised effectively by a strong local independent candidate. What follows is a more detailed examination of the case of Indi, in order to shed light on the extent to which this independent win was an aberration or in line with broader electoral expectations about minor parties and independents in Australian and comparative politics.

\section{Paradox or pattern? The result in Indi}

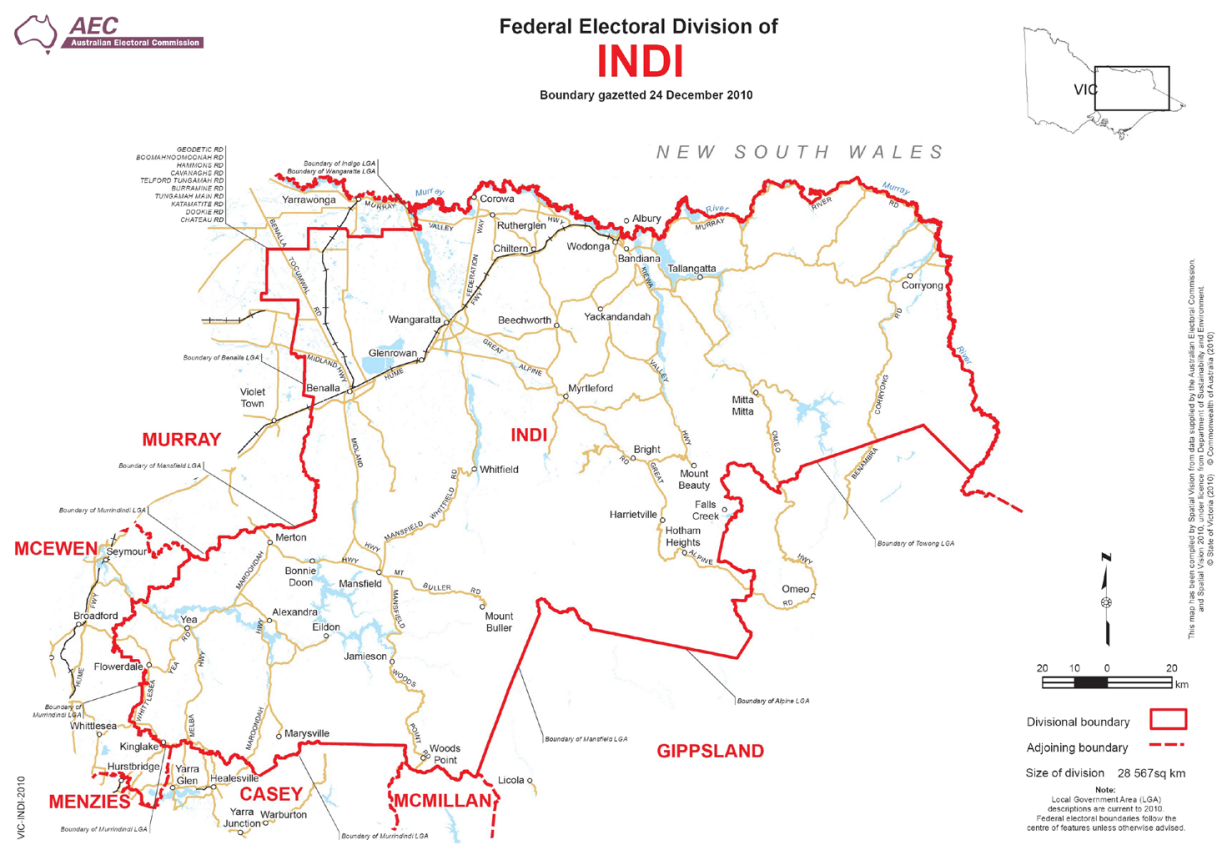

\section{Figure 1: Map of Indi}

Source: Australian Electoral Commission.

The Victorian federal division of Indi has been located in the north-east of the state since its creation in 1902 but the 2010 electoral redistribution added nearly 10,000 voters from its south-western neighbour McEwen and the seat now

5 We wish to acknowledge the sudden passing of our close friend and colleague Dennis Woodward in 2012. Dennis was a regular election book contributor. 
stretches from outer north-western Melbourne to the New South Wales border. While classified as 'rural' by the Australian Electoral Commission (AEC), the division is notable for its diversity. Most of its population resides in the three large towns of Wodonga $(30,000)$, Wangaratta $(27,000)$ and Benalla $(14,000)$, but there are also many smaller towns such as Yea $(1,600)$ and hamlets such as Harrietville (217). The western part of Indi is national park containing the snow resort of Falls Creek and is only lightly populated (AEC 2010).

Indi's industry is more diverse than most rural divisions: 9 per cent of its workforce is employed in agriculture compared to 5 per cent nationally, but 13 per cent is in manufacturing and 7 per cent in accommodation and food services - tourism is a growing sector of the local economy. The increases in employment in the large towns are among professionals and community and personal service workers, with the biggest decline being among labourers. Like so much of regional Australia, it is not particularly wealthy: 26 per cent of families earn $\$ 650$ or less per week and only 11 per cent earn more than $\$ 2,000$ per week. Forty-two per cent of its population left school at year 10 or before, with only 21 per cent holding university qualifications. ${ }^{6}$

The division's socio-economic diversity is not reflected in its electoral pedigree and for 105 of its 111-year history it has been held by the conservative parties. From 1937 to 1977 it was in the hands of the Country [National] Party, but longtime sitting member Mac Holten lost the seat to the Liberals' Ewen Cameron in 1977. Cameron was succeeded by Lou Lieberman and his retirement at the 2001 election saw a hotly contested pre-selection ballot and an unlikely winner, Sophie Panopolous, by just one vote. Panopolous was a 31-year-old Melbourne lawyer who had been deeply involved in right-wing politics at the University of Melbourne. She had no prior connection to Indi but, according to one Liberal source, 'She was the star performer of the day by a long way' (Harvey 2010). It was later revealed that she had been able to relocate to Wangaratta to campaign for pre-selection by way of a $\$ 100,000$ gift from her partner since 1995, former Dean of the Melbourne Law School, Professor Colin Howard (Bachelard 2011). She had come to prominence as an assertive monarchist during the 1999 republican debate and had impressed fellow monarchist Tony Abbott. Panopolous won the 2001 election easily with 40 per cent of the primary and 60 per cent of the twoparty-preferred vote. She was then a beneficiary of the 'Latham election' of 2004, winning 62 per cent of the primary vote. Thereafter, her vote share fell by 10 percentage points by 2010 despite the absence of Nationals candidates and the chronic weakness of the local ALP.

As a backbencher Panopolous cultivated a confrontational political persona and has been described as 'one of the Liberal Party's most committed ideological

6 These data are drawn from Nelson (2010) and Australian Bureau of Statistics (2011). 
warriors' (ABC TV 2013). After supporting Malcolm Turnbull's successful 2008 challenge to Opposition Leader Brendan Nelson she was made Shadow Minister for Early Childhood Education, Childcare, Women and Youth. When Turnbull himself was defeated in the party room by one vote in late 2009, Panopolous (now Mirabella following her 2006 marriage to Greg, a former army officer) was elevated to the job of Spokesperson for Innovation, Industry, Science and Research. This promotion anticipated her joining cabinet should the Coalition win in 2013. Senior shadow ministers often have duties that take them away from their electorates but by 2012 some Indi residents formed the view that Mirabella was focusing too much on her future ministerial career, Liberal Party factional politics and the internal machinations of the increasingly dysfunctional Wangaratta City Council. It was reported that at meeting of constituents who wished to raise the issues of broadband and mobile black spots, Mirabella told them that 'the people of Indi weren't interested in politics' and that 'there are three issues: cost of living, cost of living, cost of living.' The meeting lasted 11 minutes (Elder 2013).

The constituents who went away disappointed with the local member's response were members of a community organisation established in mid-2012 called Voice for Indi $(V 4 i)$ and included the person who was eventually to win the seat, Cathy McGowan AO. V4i began by conducting kitchen table conversations around issues local to the area and, by May 2013, 425 people had participated in 53 such conversations (Voice for Indi 2013). Initially these meetings were conducted confidentially because of a concern that opposition to the local political elite might attract future retribution in the form of loss of government contracts or removal from local boards (Klose and Haines 2013: 2; V4i Forum 2013). One local Liberal Party official claimed that V4i had started as 'a secret women's group, meeting in a public library. They were carrying on like they were in fear of their lives. It sounded like witchery to me' (Elder 2013).

Nevertheless the organisation flourished, attracted increasing media attention and established an impressive presence online. Eventually a decision was made to enter the electoral fray and support a candidate at the 2013 federal election. Somewhat reluctantly McGowan agreed to be that candidate. She was no political ingénue: her family had lived in the locality for generations; she was a sheep farmer and was active in rural politics as a lobbyist for the National and Victorian Farmers Federations; she had served as a staff member to an earlier Liberal member for Indi and had been a teacher and academic. She was a member of or had easy entrée to a plethora of local organisations. McGowan is difficult to pigeonhole ideologically - she is a Catholic who supports marriage equality, is 'embarrassed' by Australia's asylum seeker policy and believes in climate change. She rejects the description 'conservative' as old politics but supports free trade, strongly advocates for small business and claims her main objective 
is to re-build the local community and gain for it 'really good infrastructure' (Alcorn 2013; Whinnett 2013). Thus, the contest for Indi was set to be between a sitting member justifiably anticipating a cabinet career and a high profile localist independent.

Over the past two decades hundreds of independents have contested House of Representatives divisions and only a handful have been successful - most of the remainder have not only lost but also forfeited their deposits by failing to win at least 4 per cent of the primary vote. Predicting the likely victory of a firsttime independent is a highly imprecise science and McGowan did not emerge as electable until about two weeks before the 7 September polling day. She did, however, have in her favour several factors unusual for independents, the most obvious of which was the existence of hundreds of supporters in V4i: her campaign launch in Wodonga on 4 August drew a crowd of 400. By election day, McGowan had 600 registered campaign workers, all of whom had been trained in electioneering techniques and were required to sign a volunteer agreement that committed them to behaving ethically and respectfully-especially to political opponents.

McGowan, in effect, ran a two-tiered campaign: one of the traditional type for regional areas involving extensive door-knocking, leaflet distribution, public and private meetings and phone calls; and a parallel campaign that made extensive use of social media. The second campaign was coordinated by a group of young people - many of whom were the candidate's nieces and nephews (she has 12 siblings) — who were known as 'Indi Expats'. They had been raised locally, had gone to the city for tertiary education, expressed a wish to return but were dissuaded by poor transport and communications infrastructure. They made extensive use of Twitter and Facebook and the cloud-based online software package NationBuilder which enabled the efficient organising of on-the-ground volunteers (Fogarty 2013). This strategy also permitted crowd funding which netted an impressive $\$ 120,000$ in small donations. Tony Windsor was the only other independent who had managed to raise such a large amount of campaign finance and then only for his last election in 2010 (Klose and Haines 2013). The donations allowed McGowan to engage in extensive advertising and to open campaign offices in four towns. Mirabella and the Liberal Party allegedly spent $\$ 500,000$ trying to retain the seat.

The Mirabella and McGowan campaigns were vastly different in both content and style. The sitting member essentially channelled the national Coalition campaign into Indi stressing the need to 'turn back the boats' and repeal the carbon and mining taxes. The independent concentrated almost exclusively on the need to upgrade local infrastructure, especially in the areas of transport, telecommunications and health. While McGowan refused to criticise Mirabella personally and forbade her team from doing so, the latter's political aggression 
both locally and via her regular appearances on the ABC TV show Q\&A was a major issue in the campaign (Lette 2013: 10). Barnaby Joyce's praising comment that Mirabella 'to be honest' was someone with 'a bit of mongrel' may have been better left unsaid (Kotsios 2013a). Mirabella ran a very traditional campaign via multiple media advertisements, letters, leaflets and 'robo-polling', but hardly used social media at all. She also highlighted a number of visits to the electorate by Joe Hockey, Barnaby Joyce, Malcolm Turnbull and former treasurer Peter Costello.

The McGowan campaign gained prominence by adapting international 'coloured revolutions' techniques and kitted out supporters with bright orange t-shirts. Volunteers were given 'full autonomy and responsibility for activating their part of the electorate' and devised some innovative campaign events (Klose and Haines 2013). For example, one group 'cash mobbed' a florist shop and each purchased $\$ 20$ worth of flowers which were then donated to local nursing homes to the approval of the local media. Given their electoral inexperience and the free rein given to volunteers, there was an ever-present possibility for the de-railing of the McGowan campaign, though in the end it was remarkably gaffe-free. Mirabella was not to be so fortunate. On the eve of the poll she was required to support the Coalition's promise to abolish the Regional Development Australia Fund which had allocated \$5.6 million to projects in Wodonga, Rutherglen, Mount Beauty and Wangaratta - all in Indi (Kotsios 2013b).

The Mirabella campaign also encountered problems with the Liberals' coalition partner, the Nationals. The north-east of Victoria has long been a Nationals stronghold with the majority of the local state electoral districts held by that party. Relations between the Victorian branches of the two parties were tense in 2013 because of the Liberal Party's decision to contest the north-western Victorian seat of Mallee in a three-way contest despite the discouragement of Opposition Leader Abbott (Ferguson 2013). Rumours began to circulate that Nationals branch members in Indi were supporting McGowan's campaign and these gained traction when the former Nationals member for the state seat of Murray Valley, Ken Jasper, publicly endorsed her as did former Liberal Prime Minister Malcolm Fraser (Harris 2013). Senior Nationals figures then unsuccessfully attempted to have Jasper withdraw his support, but no disciplinary action was taken against any member of the Nationals. In his election report to the Liberal Party's state council in December 2013, past president and former Howard Government minister, David Kemp, complained that while Mirabella was supported by the federal and state leaderships of the Nationals, 'there were some Nationals who worked for McGowan' and this cost the Liberal Party the seat (Campbell 2013).

Local government plays a more prominent role in the politics of regional Australia than in the major cities and Mirabella's engagement with the Rural City of Wangaratta Council did not assist her re-election prospects. At the October 
2012 council elections only two of the serving seven councillors were returned. Four of the newly elected members constituted a 'team' whose campaigns had been facilitated by one of Mirabella's staff members (Becker 2013). It was later revealed that the member for Indi had written them congratulatory letters in which she accused the former council of running 'a protection racket' and that it was time for 'a clean up' (Johnson 2013). What united the four new councillors was their opposition to Wangaratta City's draft Rural Land Strategy that sought to regulate the building of dwellings on farm land (Rural City of Wangaratta 2013). The plan, issued in March 2011, had attracted large protest meetings across the region and was a major issue in the October 2012 election. From its first meeting the new council was riven with conflict with the majority, and Councillor Julian Fidge (a local GP and former army reservist) especially was openly critical of other councillors, the CEO (whom he wished to dismiss) and other senior officers. In March 2013 the Minister for Local Government voiced public concern about the behaviour at the council and required it to renew its code of conduct (Powell 2013a).

This action had little obvious effect and in May 2012 the CEO directed that staff were to have no dealings with $\mathrm{Cr}$ Fidge who was also banned from some areas of the council offices (Burke 2013). By May one of the minority councillors had resigned and most of the senior staff were on stress leave. In mid-August a Municipal Association of Victoria (MAV) Councillor Conduct Panel suspended Cr Fidge for two months for bullying behaviour. Describing the panel's procedures as 'corrupt and biased' he appealed the decision to the Victorian Civil and Administrative Tribunal (VCAT) (Johnson 2013; Fidge 2013). On 30 August the CEO and five other senior staff left the council. To this point the council had spent $\$ 1.5$ million attempting to resolve the disputes (Twomey 2013). In the interim, Minister Powell had commissioned reviews of the council by the Inspector of Municipal Administration and the Local Government Investigations and Compliance Inspectorate. Both were scathing in their criticism of the behaviour of the majority of councillors and the inspector described Cr Fidge as engaging in an 'abuse of process for political point scoring' (Stephenson 2013: 8). On 19 September the state government sacked the Rural City of Wangaratta and appointed administrators (Powell 2013b: 30-3) whereupon Julian Fidge called the minister 'a fascist' (Willingham 2013).

Since Cr Fidge had publicly thanked Mirabella for her support at the height of the conflict - 'she has been quietly supportive and encouraging' (Becker 2013) and acted as one of her scrutineers at the 2013 election count (Kotsios 2013c), it was difficult for her to distance herself from the negative fall-out of the 10-month imbroglio and the external disruption it caused. The inspector's report alluded at length to the impact the council's dysfunctionality had on the economic and other operations of the city (Stephenson 2013b: 8-10). Nevertheless, a month 
out from polling day Mirabella stated that she 'was absolutely not' worried about losing Indi (Kotsios 2013d). But at the same time her media advisor sent an email to Liberal supporters complaining that they were being 'outgunned by a far more active and enthusiastic campaign team' and urged them to flood the electorate's newspapers with pro-Mirabella letters (Morgan 2013). While the Liberal Party conducted polling and focus groups in Indi, there was no polling by the major companies. A ReachTEL poll in late August recorded Mirabella on 47 per cent of the primary vote and McGowan on 25 per cent (Kotsios 2013e). This was sufficient evidence to make the Liberal Party panic and it poured extra resources and staff into Indi in the last two weeks of the campaign. Also, the theme of the campaign was shifted from positive to negative. Most of the billboards and other signage had Mirabella's photo removed and replaced with slogans denigrating independents such as 'Independents won't stop the boats'. On the eve of polling, Opposition Leader Tony Abbott made personal calls to all local media in support of Mirabella (Johnson 2013). Sportsbet's last odds were Mirabella \$1.90, McGowan \$1.80, whereas at the start of the campaign the independent had been a 50 to one outsider.

The final Indi outcome had a number of interesting features. Cathy McGowan polled 31.18 per cent of the primary vote (27,763 votes) to Mirabella's 44.68 per cent $(39,785$ votes) (AEC 2013). However, after the distribution of preferences, McGowan won Indi by 439 votes to become the first female independent to win a regional House seat in Victoria, and Mirabella was the only Coalition casualty of the 2013 election.

The reason for this result is that the independent lifted her primary vote to 50.25 two-candidate-preferred, whereas Mirabella could add only 5.07 per cent to her primary vote through preferences. Historically it is most unusual for a candidate with nearly 45 per cent of the primary vote not to go on to claim the seat (Hughes and Costar 2006: 69). McGowan received strong preference flows from the ALP ( 89 per cent) and the Greens (88 per cent). While 11 candidates contested the seat, only three of the nine losing contestants officially preferenced Mirabella-Family First, Rise Up Australia and Katter's Australia Party - but she received a majority only from Family First (52 per cent). Indi in 2013 had 103 polling places: McGowan polled well in the large booths in Wodonga, Wangaratta and Benalla, but she was competitive right across the division, except in 11 very small booths. When the Senate count in Indi is examined it shows that 4,471 electors who chose the Coalition team did not vote for Mirabella in the House. As expected, the sitting member won the postal votes by 56.9 per cent to 43.0 per cent. The seat was declared on 19 September but not before a minor counting error when a pile of McGowan's votes was wrongly numbered '1003' when it should have been '2003' (Ferguson 2013). Sophie Mirabella did not challenge the result. 


\section{Conclusion}

In comparative perspective, Australia's history and contemporary experience of electing independents is unusual. Although independents are most likely to succeed in majoritarian systems with preferential voting in place, it is much less common to find independents working to support governments, to introduce progressive and inclusive policies, and seeking to reform parliamentary process (Brancati 2008; Hijino 2013). The election of independents is also more likely to occur in new democracies where party organisations are still developing and party loyalties less entrenched. Yet in Australia, the election of independents has become an enduring low-level trend over the past three decades despite continued major party loyalty, and in the 43rd parliament it is evident that these representatives laboured to enhance democratic practice. The case of Indi reinforces the argument that independents will often succeed when voters believe political parties have failed to address local and societal interests (Costar and Curtin 2004; Greenberg 1994; Weeks 2011). McGowan's success is also a reminder that majoritarian preferential systems (particularly those with compulsory voting) can facilitate candidate-centred politics that advantages strong independent candidates.

\section{References}

Australian Broadcasting Commission (ABC). Q\&A. Viewed 4 January 2014: $<$ www.abc.net.au/tv/txt/s3016955>. Panelist: Sophie Mirabella.

Australian Bureau of Statistics (ABS). 2011. Community Profiles of Wodonga, Wangaratta and Benalla.

Australian Electoral Commission (AEC). 2013. House of Representatives Results. AEC, 4 November 2013, viewed 17 July 2014: < results.aec.gov.au/17496/ Website/HouseResultsMenu-17496.htm>.

AEC. 2010. Federal division of Indi. Map, AEC, viewed 20 January 2014: <www. aec.gov.au/profiles/vic/files/2010/2010-aec-a4-map-vic-indi.pdf $>$.

Alcorn, Gay. 2013. 'Winds of change may begin with one voice'. The Age, 27 September.

Bachelard, Michael. 2011. 'Power, love and money'. The Age, 23 September.

Bean, Clive and McAllister, Ian. 2012. 'Electoral Behaviour in the 2010 Australian Federal Election'. In Marian Simms and John Wanna (eds), Julia 2010: The caretaker election, Canberra: ANU E-Press. 
Bean, Clive and Papadakis, Elim. 1995. 'Minor Paries and IndependentsElectoral bases and future prospects'. Australian Journal of Political Science 30(1): 111-26.

Becker, Joshua. 2013. 'Cr Julian Fidge grateful for Sophie Mirabella's counsel'. ABC Radio Goulburn Murray, 22 August, viewed 20 January 2014: <www. abc.net.au/local/audio/2013/08/22/3831693.htm>.

Bolleyer, Nicole and Weeks, Liam. 2009. 'The puzzle of non-party actors in party democracy: Independents in Ireland'. Comparative European Politics 7(3): 299-324.

Brancati, Dawn, 2008, 'Winning Alone: The Electoral Fate of Independent Candidates Worldwide'. The Journal of Politics 70(3): 648-62.

Brent, Peter. 2013. 'Mumble Election Tables: Minor party preference flows 2013 federal election in descending order of 2010-2013 change'. Mumble, viewed 6 December 2013: <www.mumble.com.au/fedelect13/wall/others/prefstots/ Prefflowsbychang 10-13.HTM $>$.

Burke, Steven. 2013. 'You've got mail, Cr Fidge'. Wangaratta Chronicle, 24 May.

Campbell, James. 2013. 'Nationals blamed for Liberal loss of Indi'. Herald Sun, 1 December.

Costar, Brian and Curtin, Jennifer. 2004. Rebels with a Cause. Independents in Australian Politics. Sydney: UNSW Press.

Curtin, Jennifer. 2004. The Voice and the Vote of the Bush: The representation of rural and regional Australia in the Federal Parliament. Canberra: Department of Parliamentary Services and the Parliamentary Library.

Curtin, Jennifer and Woodward, Dennis. 2012. 'Rural and Regional Australia: The ultimate winners?'. In Marian Simms and John Wanna (eds), Julia 2010: The caretaker election, Canberra: ANU E-Press.

Elder, John. 2013. 'Ironies abound in the battle for Indi'. The Sydney Morning Herald, 15 September.

Evershed, Nick. 2013. 'Was Julia Gillard the most productive prime minister in Australia's history?' Guardian Australia, 28 June, viewed 21 July 2014: $<$ www.theguardian.com/news/datablog/2013/jun/28/australia-productiveprime-minister $>$.

Ferguson, John. 2013. 'Indi row "dire" for Mirabella'. The Australian, 4 September. 
Fidge, Julian. 2013. 'Cr Fidge defends actions, will appeal'. Wangaratta Chronicle, 14 August.

Fogarty, Nick. 2013. 'New software helps campaign community organising'. ABC Radio Goulburn Murray, 25 July, viewed 20 January 2014: <www.abc. net.au/local/stories/2013/07/25/3810967.htm $>$.

Greenberg, Stanley B. 1994. Third Force: Why Independents Turned against Democrats - and How to Win Them Back. Washington: Democratic Leadership Council.

Harris, Rob. 2013. 'McGowan finds her voice in Indi'. Weekly Times, 5 September.

Harvey, Michael. 2010. 'Monarchist about face'. Herald Sun, 23 October.

Hawker Britton. 2013a. How the Independents Voted. September, viewed 25 October 2013: <www.hawkerbritton.com/hawker-britton-media/federalact/632/how-the-independents-voted-in-the-house-of-the-43rd-parliament. htm $>$.

Hawker Britton. 2013b. Independents' voting record in the House of the 43rd Parliament. September, viewed 25 October 2013: <www.hawkerbritton. com/hawker-britton-media/federal-act/632/how-the-independents-votedin-the-house-of-the-43rd-parliament.htm $>$.

Hijino, Ken Victor L. 2013. 'Liabilities of Partisan Labels: Independents in Japanese Local Elections'. Social Science Japan Journal 16(1): 63-85.

Hughes, Colin A and Costar, Brian. 2006. Limiting Democracy: The Erosion of Electoral Rights in Australia. Sydney: UNSW Press.

Johnson, David. 2013. 'Pushing The Envelope'. Border Mail, 12 February.

Klose, Cambell and Haines, Nick. 2013. 'From little margins, big margins grow'. The Canberra Times, 19 October.

Kotsios, Natalie. 2013a. 'Barnaby Joyce backing Sophie Mirabella'. Border Mail, 23 August.

Kotsios, Natalie. 2013b. 'Sophie stands by regional cuts'. Border Mail, 7 September.

Kotsios, Natalie. 2013c. 'Cathy McGowan wins two cities'. Border Mail, 10 September.

Kotsios, Natalie. 2013d. 'Sophie Mirabella 'absolutely not' worried about losing Indi'. Border Mail, 8 August. 
Abbott's Gambit: The 2013 Australian Federal Election

Kotsios, Natalie. 2013e. 'Battle 'boost' for Sophie'. Border Mail, 6 September.

Lette, Kate. 2013. 'Yes She Can', Weekend Australian Magazine, 19-20 October.

Maher, Sid. 2013. 'Abbott's plea: don't leave us hanging'. The Australian, 6 September.

McKenna, Michael and Maher, Sid. 2013. 'Minor parties waste of your vote: Abbott'. Weekend Australian, 7-8 September: 8.

Moon, Jeremy. 1995. 'Minority Government in the Australian States-From Ersatz Majoritarianism to Minoritarianism'. Australian Journal of Political Science 30(1): 142-63.

Morgan, Shana. 2013. 'Liberal letters spark storm'. Wangaratta Chronicle, 9 August.

Neales, Sue. 2013. 'PM gives Katter Lay of the Land'. Weekend Australian, 31 August-1 September.

Nelson, Paul. 2010. Electoral division rankings: 2006 Census (2009 electoral boundaries). Parliament of Australia Research Paper, no. 18, 28 May: 130.

Newspoll. 2013a. Weekend Australian, 31 August-1 September.

Newspoll. 2013b. Weekend Australian, 7-8 September.

Oakeshott, Rob. 2013. 'Member for Lyne's valedictory address'. Port News, 30 June, viewed 10 October 2013: <www.portnews.com.au/story/1606474/ member-for-lynes-valedictory-address $/>$.

Papadakis, Elim, and Bean, Clive. 1995. 'Independents and Minor Parties - The Electoral System'. Australian Journal of Political Science 30(1): 97-110.

Parliamentary Library. 2013. The Hung Parliament: procedural changes in the House of Representatives. Research Paper 2013-14, 22 November. Canberra: Politics and Public Administration, Parliamentary Library.

Powell, Jeannette. 2013a. 'Wangaratta Council to renew Code of Conduct'. Media Release, 21 March.

Powell, Jeannette. 2013b. 'Local Government (Rural City of Wangaratta) Bill'. Victorian Parliamentary Debates Assembly, 19 September: 30-3.

Rodriques, Mark and Brenton, Scott. 2010. The age of independence? Independents in Australian parliaments. Research Paper No. 4. 2010-11. 21 September. Canberra: Parliamentary Library. 
Rural City of Wangaratta. 2012. Rural Land Strategy: 1-27.

Smith, Rodney. 2006. Against the Machines: Minor Parties and Independents in New South Wales 1910-2006. Sydney: Federation Press.

Stephenson, Peter James. 2013. Report on the Monitoring of the Operations and Governance of Wangaratta Rural City Council. Melbourne, Victorian Government Printer, September: 1-12.

Twomey, Sharon.2013. 'Dysfunctional Wangaratta council sacked'. Weekly Times, 18 September.

Voice for Indi. 2013. 'Kitchen Table Conversations'. Voice for Indi, viewed 20 January 2014: <www.voiceforindi.com/report_info>.

Voice for Indi Forum. 2013. Benalla Bowls Club, 9 November.

Weeks, Liam. 2009. 'We Don't Like (to) Party. A Typology of Independents in Irish Political Life, 1922-2007'. Irish Political Studies 24(1): 1-27.

Weeks, Liam. 2011. 'Rage Against the Machine: Who is the Independent Voter?' Irish Political Studies 26(1): 19-43.

Whinnett, Ellen, 2013. 'Giant Killer'. Herald Sun, 14 September.

Willingham, Richard. 2013. 'MP labelled a "fascist" after council axed'. The Age, 19 September.

Windsor, Tony. 2013. 'Valedictory Speech'. House of Representatives, Commonwealth of Australia, Canberra, 26 June. 
This text taken from Abbott's Gambit: The 2013 Australian Federal Election, edited by Carol Johnson and John Wanna, published 2015 by ANU Press, The Australian National University, Canberra, Australia. 